1508

日本機械学会論文集 (A 編)

論文 No. 09-0426

75 巻 759 号 (2009-11)

\title{
パイプジョイント部の耐力に関する数值解析的検討*
}

陳玳珩*1, 桑子寛*2

\section{Numerical Study on Strength of Pipe Joint}

\author{
Dai-heng CHEN*3 and Hiroshi KUWAKO \\ *3 Department of Mechanical Engineering, Tokyo University of Science, \\ 1-3 Kagurazaka, Shinjuku-ku, Tokyo, 162-8601 Japan
}

\begin{abstract}
In this study, the strength of $\mathrm{T}$-joint and $\mathrm{Y}$-joint is analyzed based on numerical results of FEM. It is found that the joint strengths are proportional to a $\lambda$-th power of thickness $T$ of chord tube for various joints with a fixed branch-to-chord diameter ratio $d / D$. The index $\lambda$ changes with $d / D$, and in the range of $d / D=0.1 \sim 0.91$, it is $\lambda \cong 1.93 \sim 1.55$, with small value corresponding to large $d / D$. A compressive axial force in chord will reduce the joint strength, and it is also found that the strengthreduction ratios for $\mathrm{Y}$-joint are the almost same as those for $\mathrm{T}$-joint having the same $T$ and $d / D$. Also, the joint strengths are influenced by span-length of the chord. The joint strengths decrease as span-length increases. However, the influence is small for small $d / D$.
\end{abstract}

Key Words: Tubular Truss Joint, T-Joint, Y-Joint, Collapse Behavior, Strength, FEM

\section{1. 緒言}

海洋構造物や大型空間構造物に鋼管トラス構造は 多く利用されているため, 鋼管トラス構造のジョイン ト部の而力に関する研究は，古くから行われている (1) (5). しかし，この中には FE の数值解析に基づく 研究もある (6) が，既存の研究は実験によるものが大 部分を占め，提案されている設計式は限られた実験条 件により推定された式である.そこで本研究は，鋼管 トラス構造のジョイント部の崩壊挙動について, 汎用 有限要素法解析ソフトを用いた解析を行い, 継手部の 耐力と継手部周辺の応力分布に関して検討を行うこと で, ジョイント部の崩壊挙動および耐力に関してより 広範囲の知見を得ようとするものである。

\section{2. 数值解析方法}

本研究では，図 1 に示すようなT-Joint と Y-Joint 形 状の解析モデルを用いて，支管に軸方向圧縮荷重を与 えた際のジョイントの変形挙動について汎用ソルバー MSC. Marc による大変形・弾塑性 FEM 解析を行う. 境界条件俚主管の雨端を単純支持とし，支管の上側か ら移動剛体壁を接触させることにより圧縮荷重を載荷

* 原稿受付 2009 年 5 月 7 日.

*1 正員, フェロー, 東京理科大学工学部 (\$162-8601 東京都新 宿区神楽坂 1-3).

*2（株）サニュウシビルエンジニアリング (丞 111-0053 東京都 台東区浅草橋 $5-2-3$ 浅草橋鈴和ビル).

E-mail : chend@rs.kagu.tus.ac.jp
する・

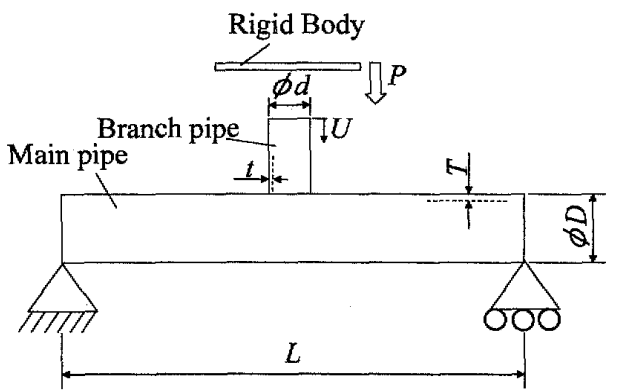

(a) T-joint

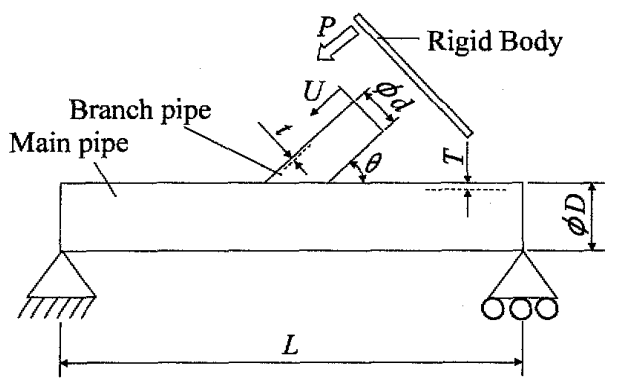

(b) Y-joint

Fig. 1 Geometry of pipe joint

なお，材料は構造用鋼管とし，加工硬化則として降伏 後の応力とひずみの関係は, 2 直線硬化則に従うと仮定 する. 材料定数と幾何条件は, とくに断らない限り，材 料の降伏応力 $\sigma_{Y}=360 \mathrm{MPa}$, ヤング率 $E=205 \mathrm{GPa}$, ポ 
アソン比 $v=0.3$, 加工硬化係数 $E_{h}=0.01 E$ とし, また ジョイントの幾何寸法についてスパンの長さ $L / D=5$, 主管の直径 $D=318.5 \mathrm{~mm}$, 支管と主管の肉厚を同じ ものとし， $t=T=4.5 \mathrm{~mm}$ としている.

有限要素モデル化に際しては，変形が滑らかに進む ように，要素寸法を約 $20 \times 20 \mathrm{~mm}^{2}$ に設定し，4節点 四辺形双一次厚肉シエル要素を用いて離散化している. また，本解析では非線形挙動の定式化として，アップ デーテッドラグランジュ法を用いて幾何学的非線形性 を考慮し，平衡方程式を満たすための修正計算法とし てニュートン・ラプソン法を採用している.

\section{3. 解析結果および検討}

\subsection{T-ジョイントの圧潰挙動}

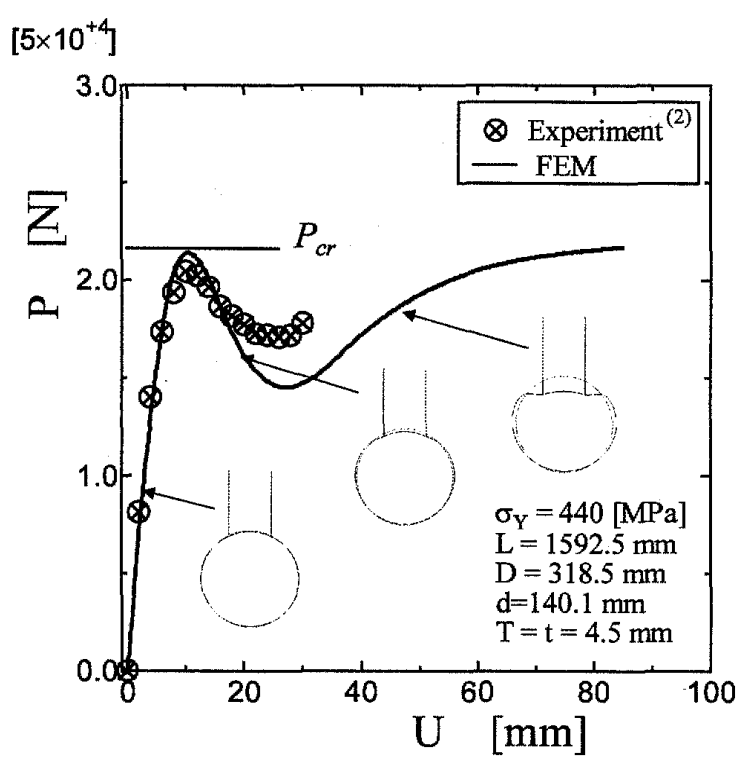

Fig. 2 Relation between compressive load $P$ displacement $U$ for a $\mathrm{T}$-joint

図 2 は, 支管と主管の直径比 $d / D=0.44$ の $\mathrm{T}-シ ゙ ョ$ イントについて求めた支管の圧縮荷重 $P$ と変位 $U$ の 関係を示すものである. 図より, 圧縮変位 $U$ の増加 に伴い, 荷重 $P$ は最初に増加するが，ある変位でピー ク值を示す. 同図に示した, その荷重ピークの前後に おける変形様子から分かるように, 圧縮荷重の変化に ピークが生じることは，主管の円筒表面に生じる凹み 変形によるものである．また，このピーク荷重が生じ るときの，支管と主管の接合部近傍の Mises の忘力分 布のコンター図（色の明るいところは応力が高いこと を意味する）を図 3 に示す（図 3 上の模式図は，各コ ンター図とジョイントの位置関係走示すものである）。 図 3 には，支管と主管の直径比が他の場合， $d / D=0.1$ と $d / D=0.26$ の場合の, ピーク荷重における主管の
Mises $の$ 応力分布のコンター図も示している. 図より わかるように，最も大きい応力は， $d / D$ が小さい場合 （例えば $d / D=0.1 ）$ 支管の両側（主管の軸力向からみ る場合の支管の両側である，それが主管の側面にある

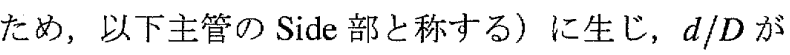
大きい場合（例えば $d / D=0.44 ）$ 支管の前後（主管の 軸方向からみる場合の支管の前後である。それが主管 の最上部にあるため，以下主管の Top 部と称する）に 生じる.

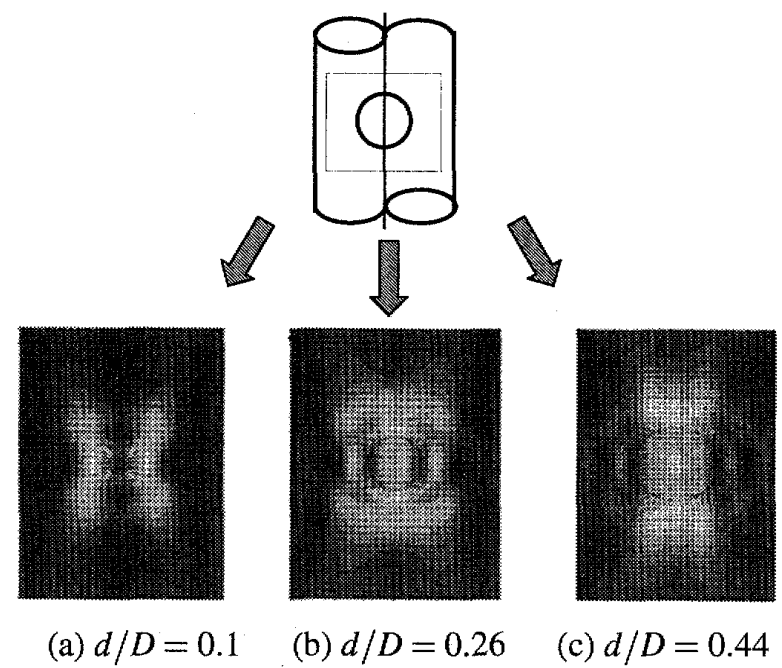

Fig. 3 Mises stress distribution near the branch-chord junction in the chord surface as the peak load arises

また，図 2 には他の研究による実験值 (2) も示して いる.この図からおかるように，実験值と FEM の数 值解析結果は比較的似た傾向を示しており数值シミュ レーションによって実験結果が再現できることを確認 できた.

以下,この荷重一変位曲線においてピークに詨忘す る崩壊荷重をジョイントの耐力 $P_{c r}$ と定義して検討を 進めていく.

図 4 は, いくつかの主管の肉厚 $T$ について, T-ジョ イントの䩂力 $P_{c r}$ と $d / D$ の関係を示すものである.こ こに図の縦軸は, 而力 $P_{c r}$ と $\left(\sigma_{Y} T^{2}\right)$ の比, $P_{c r} / \sigma_{Y} T^{2}$ で ある. 図よりわかるように，比 $P_{c r} / \sigma_{Y} T^{2}$ は主に $d / D$ の関数で, $d / D$ が大きいほど大きくなるが, 主管の肉 厚 $T$ にも関係する.

T-ジョイントの耐力 $P_{c r}$ についてこれまでの研究で いくつかの経験式 (1),(2),(4) が提案されている.

$$
\begin{aligned}
& \text { 文献 (4) では, } \quad \frac{P_{c r}}{\sigma_{Y} T^{2}}=6.43\left[1+4.60(d / D)^{2}\right] \\
& \text { 文献 (2) では, } \quad \frac{P_{c r}}{\sigma_{Y} T^{2}}=\frac{7.3}{1-0.833(d / D)}
\end{aligned}
$$


文献 (1) では， $\frac{P_{c r}}{\sigma_{Y} T^{2}}=2.14 \times f_{\beta} \cdot f_{\gamma} \cdot f_{n}$ 式(3)において,

$$
f_{\beta}=0.96+4.7(d / D)^{2}, \quad f_{\gamma}=[D /(2 T)]^{0.2}
$$

であり，また $f_{n}$ は主管の軸力 $N$ による影響を表す係 数であり，

$$
\begin{aligned}
& f_{n}=1+0.3 n-0.3 n^{2} \\
& n=N /\left(A \sigma_{Y}\right) \quad(A: \text { 主管の断面積 })
\end{aligned}
$$

である. 図 4 においては軸力 $N=0$ であるため $f_{n}=1$ である。

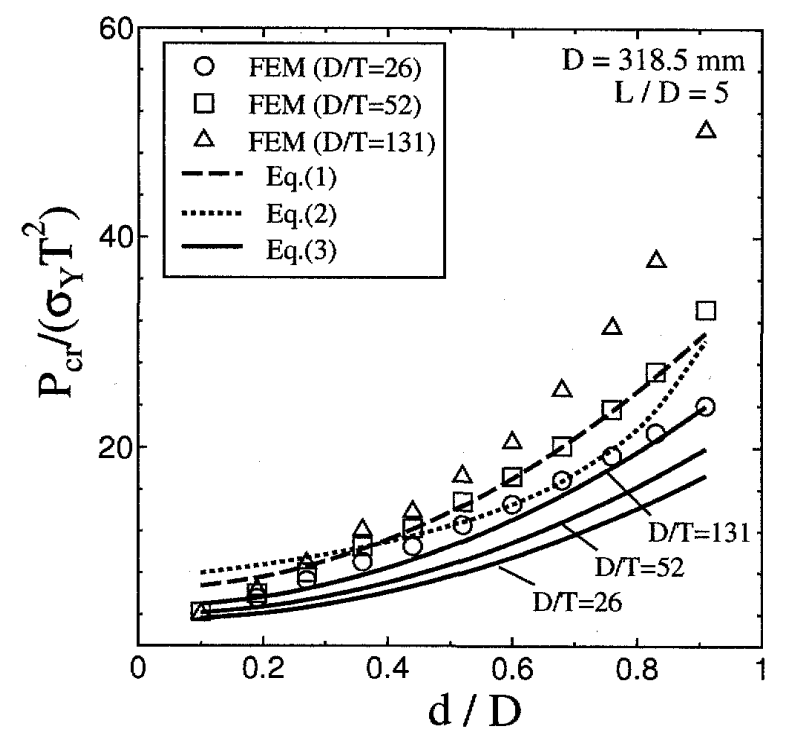

Fig. 4 Relation between strength $P_{c r}$ and $d / D$ for Tjoints

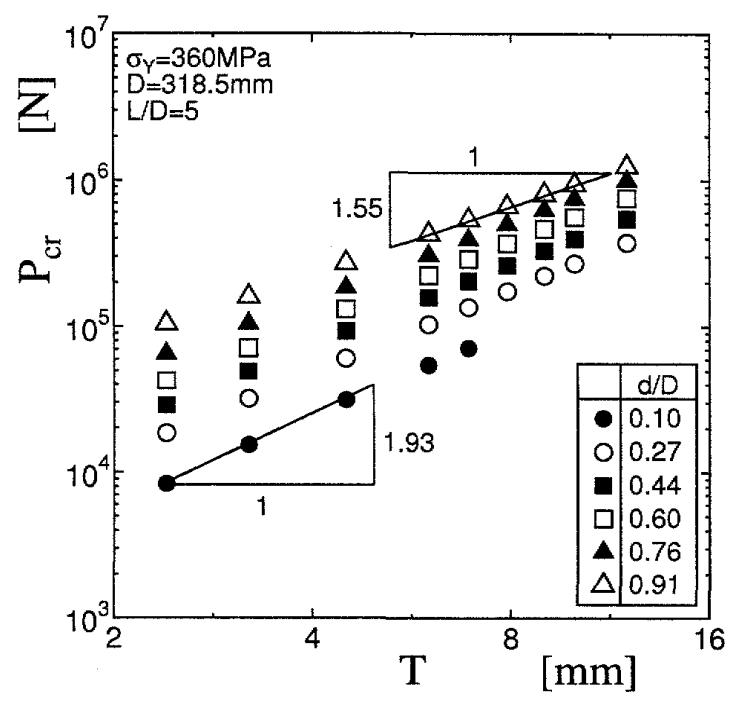

Fig. 5 Relation between strength $P_{c r}$ and thickness $T$ of chord-tube in a logarithm diagram
図 4 にはこれらの経験式による予測值も示してい る. 図中の FEM の解析結果と比較すれば分かるよう に，これらの経験式よる予測值は概ね FEM の解析結 果と一致するが，主管肉厚 $T$ によって大きい誤差が生 じる場合もある。

式 (1) と式 (2) では, 耐力 $P_{c r} を P_{c r} \propto T^{2}$ とし, 式 (3) では， $P_{c r} \propto T^{1.8}$ としている. そこで，耐力 $P_{c r}$ と主管 の肉厚 $T$ の関係を見るために, 図 5 には $d / D=0.1$, $0.27,0.44,0.60,0.76,0.91$ の T-ジョイントについて求 めた耐力 $P_{c r}$ と主管の肉厚 $T$ の值を両詨数線図で示す. 図より分かるように， $d / D$ が一定のとき，耐力 $P_{c r}$ は 次式

$$
P_{c r} \propto T^{\lambda}
$$

のように主管の肉厚 $T$ のべき乗に比例するが，その指 数 $\lambda$ は, $d / D$ によって異なり, $d / D$ が大きいほど小 さい. 図 5 では, $d / D=0.1$ のとき $\lambda \cong 1.93$ であり， $d / D=0.91$ のとさ $\lambda \cong 1.55$ である.

なお，支管の肉厚 $t$ による影響については，支管が 非常に薄くて支管の軸圧縮座屈が発生しない限り, 耐 力 $P_{c r}$ は支管の肉厚 $t$ にはほとんど依存しない.

3.2 Y-ジョイントの圧潰荷重挙動Ｔ-ジョイント では支管と主管の角度が $90^{\circ}$ であるが，Y-ジョイント では，その角度が $90^{\circ}$ ではなく，図 1(b) のように $\theta$ で 表される。

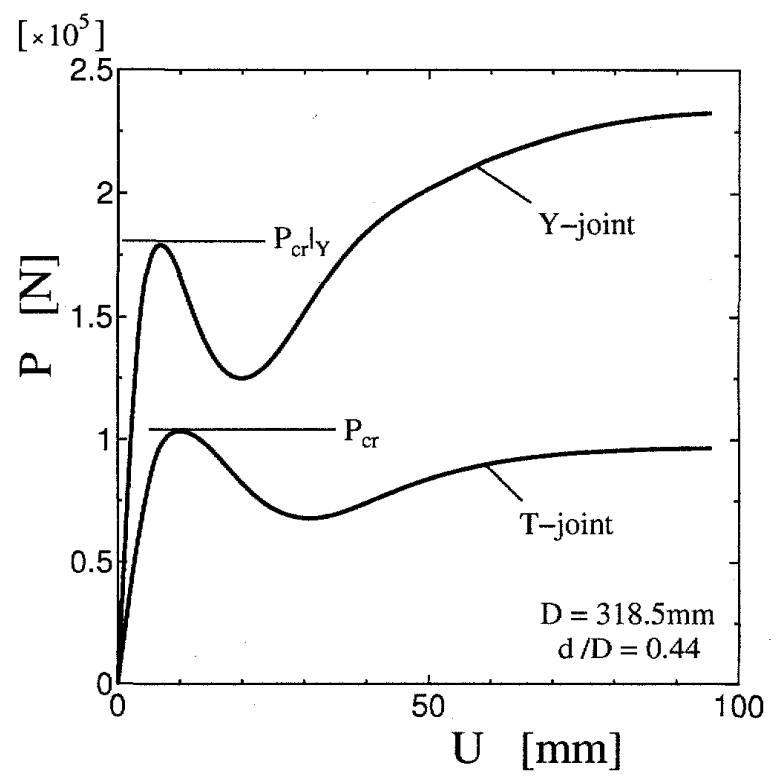

Fig. 6 The load displacement curve of Y-joint

Y-ジョイントの耐力 $\left.P_{c r}\right|_{Y}$ は，図 6 に示すように， $d / D$ および $T$ が同じ T-ジョイントの耐力 $P_{c r} よ り$ 高 い. $\mathrm{T}$-ジョイントの耐力から Y-ジョイントの耐力を推 
定するために，通常次の近似式が用いられる.

$$
\frac{\left.P_{c r}\right|_{Y}}{P_{c r}}=\frac{1}{\sin \theta}
$$

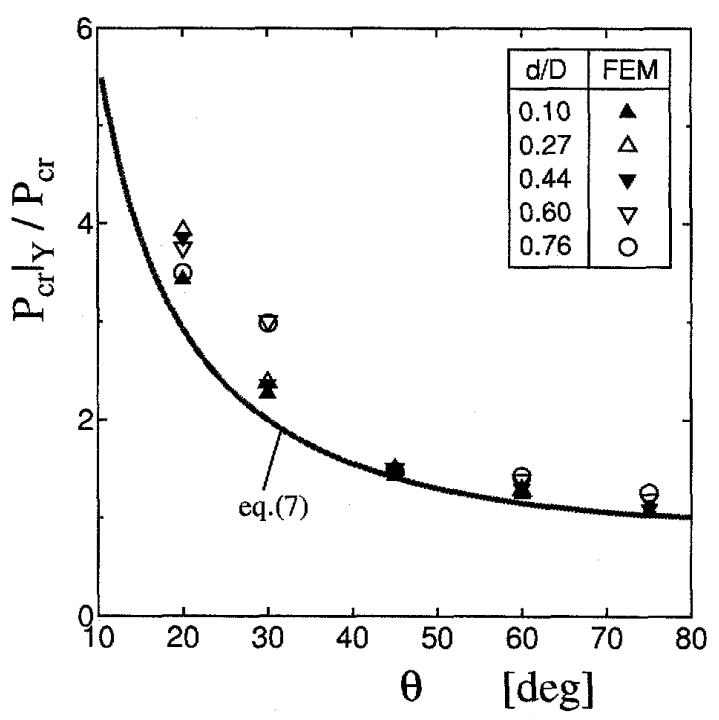

Fig. 7 Strength $\left.P_{c r}\right|_{Y}$ of Y-joints

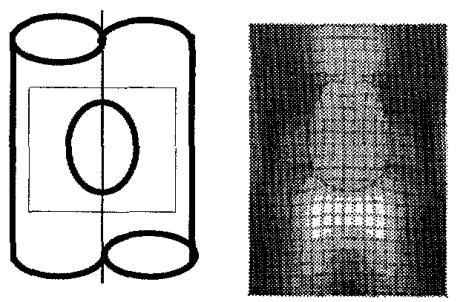

Fig. 8 Mises stress distribution in the chord surface as the peak load arises for Y-joint with $d / D=0.44$

図 7 は, 近似式 (7) による Y-ジョイント耐力 $\left.P_{c r}\right|_{Y}$ の推定值と FEM の解析で求めた值との比較を示すも のである. 図より，式 (7)による推定值は常に安全側 にあり, FEM の数值解析の值とほぼ一致する. とくに $\theta=45^{\circ}$ の Y-ジョイントにおいて式(7)による推定值は FEM $の$ 解析結果とよく致する. しかし， $\theta<45^{\circ}$ の Yジョイントにおいては FEM の解析結果は $d / D$ によっ て大きく変化し, 式 (7)による誤差が大きい. その原因 として, 荷重 $\left.P_{c r}\right|_{Y}$ による主管軸方向の分力 $\left.P_{C r}\right|_{Y} \cos \theta$ の存在が挙げられる ${ }^{(5)}$. 後述の 3,3節に述べるように, ジョイントの耐力は，主管の軸力にも関係し，軸力が 圧縮の場合降下し引張りの場合上昇する. しかし，Yジョイントに存在する主管軸方向の分力 $\left.P_{c r}\right|_{Y} \cos \theta$ の 影響は主管に働く軸力のそれと異なるようであり、こ のことはすでに他の研究者によって指摘されている ${ }^{(5)}$. 図 8 に $d / D=0.44$ の Y-ジョイントについて, ピー ク荷重が生じるときの，主管の Mises の応力分布を示 す（図 8 左の模式図は，コンター図とジョイントの位
置関係を示すものである）。図 3 と比較すれば分かる ように, 軸方向の分力 $\left.P_{C r}\right|_{Y} \cos \theta$ の存在によって, 2 つの Top 部での応力は異なり，1つでは応力が上昇し， もう1つでは応力が降下する。このようなことに加 えて，Y-ジョイントの角度 $\theta$ によって支管と主管の接 合部の幾何形状が異なることも主管の凹み変形, 寸な わちジョイントの耐力に影響を及ぼす。その結果，Yジョイントの耐力を， T-ジョイントの耐力から精度よ く予測することは困難である。ただし，d/Dが小さい とき，図 3 に示したように，主管の回みは主に主管の Side 部での応力に支配されるため, 斜め荷重 $\left.P_{c r}\right|_{Y}$ の 主管軸方向の分力 $\left.P_{C r}\right|_{Y} \cos \theta$ による影響は小さいと考 えられる。

3.3 主管の軸力による影響 実際の構造物にお いて主管には軸力が存在する. ジョイントの耐力に詨 する主管軸力の影響について既に研究が行われ設計式 が示されている(1) が，条件の困難さからとの報告例 は少ない，そこで数值シミュレーション解析により， 広範囲の条件に対する検討を試みる。

図 9 と図 10 は，それぞれ T-ジョイントと Y-ジョイ ントについて，主管に軸力がある場合のジョイントの 耐力と軸力がゼロのときの耐力の比 $P_{c r} /\left.P_{c r}\right|_{N=0}$, およ び $\left.P_{c r}\right|_{Y} /\left.P_{c r}\right|_{Y, N=0}$ を示すものである. 図から分かるよ うに，軸力が圧縮の場合に耐力は減少し，軸力が引張 の場合には耐力は上昇する，その減少および上昇の割 合はいずれもジョイントの支管と主管の直径比 $d / D$ に 関係し， $d / D$ が大きいほど大きい。また，図 9 と図 10 を比較すればわかるように，Y-ジョイントにおける耐 力の変化率 $\left.P_{C r}\right|_{Y} /\left.P_{C r}\right|_{Y, N=0}$ と T-ジョイントにおける耐 力の変化率 $P_{c r} /\left.P_{c r}\right|_{N=0}$ は，同じ軸力および同じ $d / D$ に対してほとんど同じであり，主管軸力による耐力 $P_{c r}$ への影響活，T-ジョイントと Y-ジョイントにおいてほ ぼ同じ程度だと考えられる。

図 11 に，主管に軸力がある場合とない場合の T-ジョ イントについて FEM の数值解析で求めた圧縮荷重 $P$ と支管変位 $U$ の関係曲線を示し, 支管の圧縮荷重 $P$ に おけるピークは，主管の軸力がない場合に比べて，主 管の軸力が引張の場合は遅く現れる，また，図 12 に， $d / D=0.44$ の T-ジョイントについて FEM の数值解析 で求めた支管の押し込みに伴う，主管の Top 部におけ る軸方向の応力 $\sigma_{x}$ の変化を示す. 主管の Top 部に注 目した理由は，すでに図 3 に示したようにここ場合 高い忍力が Top 部に生じ，この Top 部における応力 がジョイントの耐力 $P_{c r}$ を決めているためである，図 12 よりわかるように, 軸力がゼ口の場合, 荷重 $P$ に よって発生した Top 部での軸方向応力 $\sigma_{x}$ が圧縮応力 
であり，それは変形に伴い絶対值が大きくなり，圧縮 荷重 $P$ がピークとなるとき（図中の記号 A）に降伏忘 力に達する. そして，軸力が圧縮の場合は Top 部に生 じている圧縮応力に, 主管に導入した軸力による压縮 応力が加算されるため, 変形の早い段階から高い忘力 となるので耐力は小さくなる. 一方, 軸力が引張の場 合は，はじめに主管全体が引張応力状態であり支管に 荷重がかかると主管の Top 部には圧縮応力が発生する が初期の引張応力により相殺され耐力 $P_{c r}$ のピークを 示寸変形に達寸るのにより多くの荷重が必要となるの で耐力 $P_{c r}$ は増加すると考えられる.

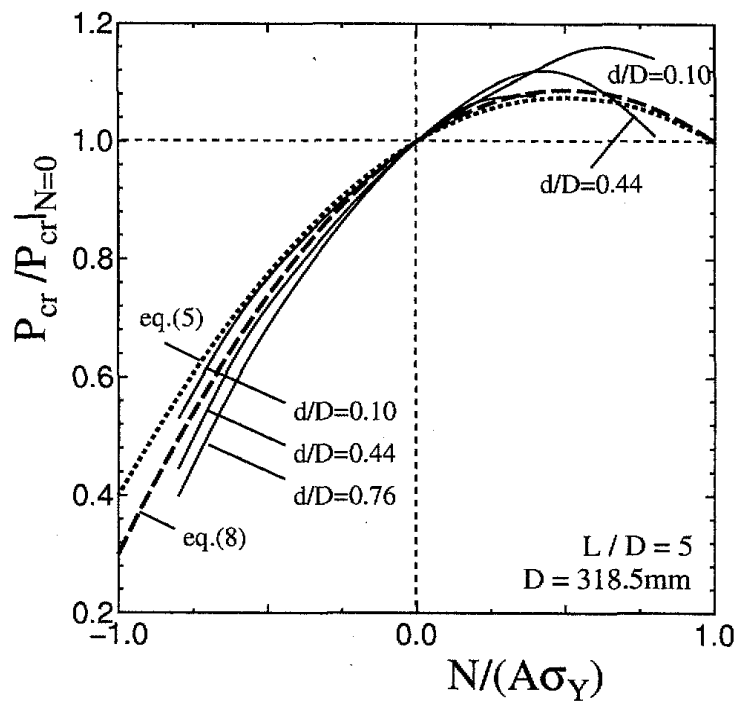

Fig. 9 Strength $\dot{P_{c r}}$ of T-joint with an action of axial force on the chord

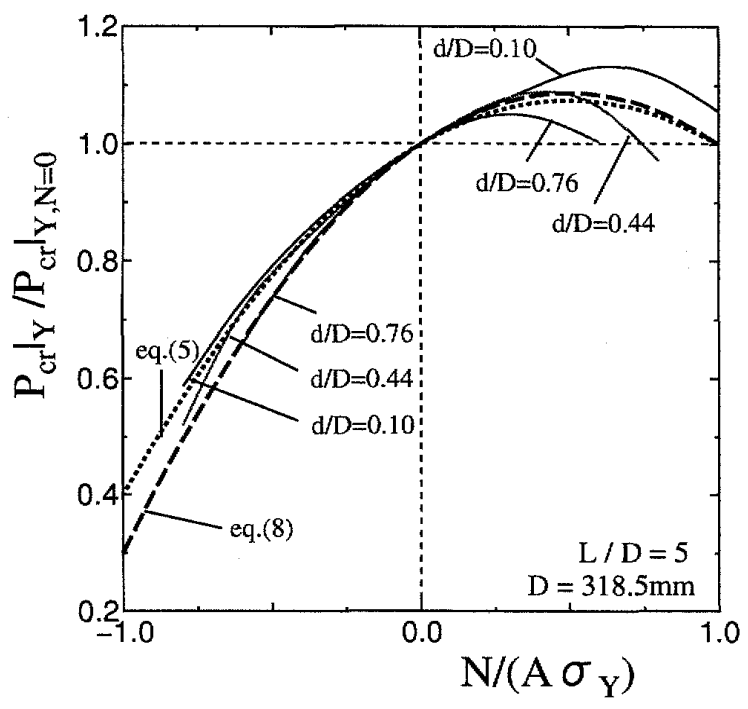

Fig. 10 Strength $\left.P_{c r}\right|_{Y}$ of Y-joint with an action of axial force on the chord

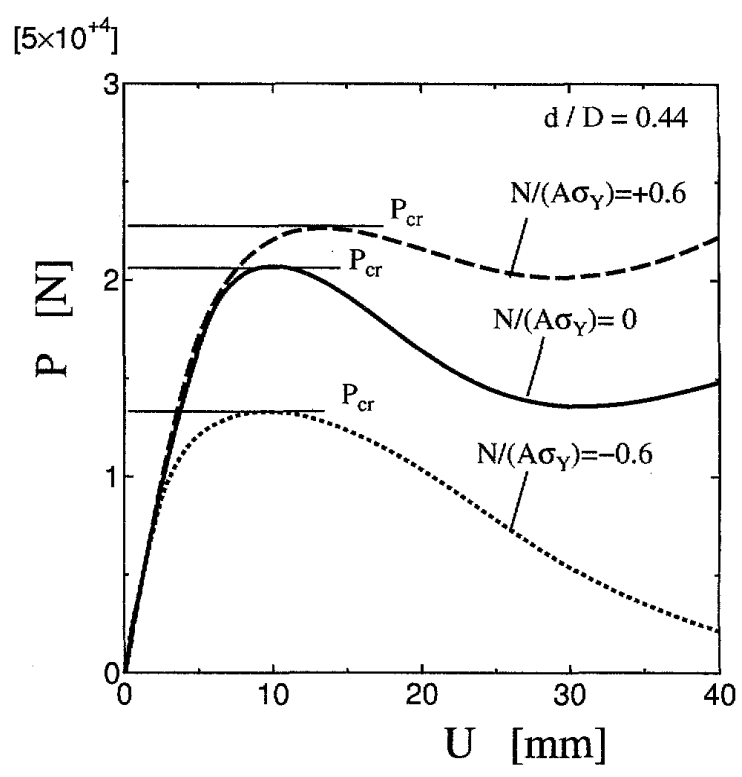

Fig. $11 \quad P-U$ curve for a joint without an action of axial force on the chord

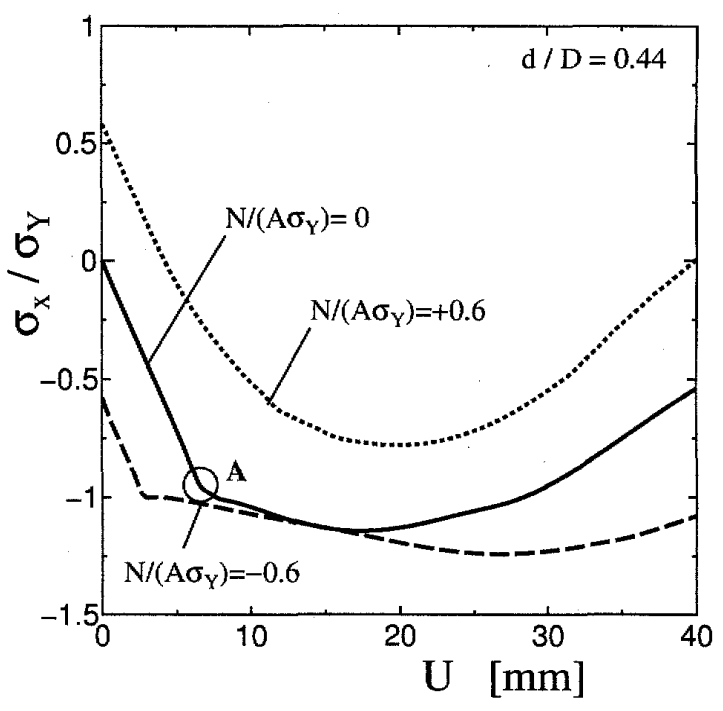

Fig. 12 Change of stress $\sigma_{x}$ in the place of Top in the chord surface

文献 (1)には軸力による影響を評価する式として式 (5) が示されているため, 図 9，10には，式(5)によ る評価值も示している. 数值解析結果任式 (5) と傾向 は同様であるが，つねに危険側にあり，とくに $d / D$ が大きいときその差が大きいことがわかる，例えば， $d / D=0.76$ の $\mathrm{T}$ ジョイントは軸力 $N /\left(A \sigma_{Y}\right)=-0.6$ の とき, FEM で求めた耐力と軸力がゼロのときの耐力 の比 $P_{c r} /\left.P_{c r}\right|_{N=0}$ は 0.600 となるが, 式 (5) ではその比 
は 0.712 であり，誤差は危険側の19\%となる.そこ で，図 9，10には，式(5) の改良式として次式

$$
\begin{array}{r}
f_{n}=1+0.35 n-0.35 n^{2} \\
n=N /\left(A \sigma_{Y}\right) \quad(A: \text { 主管の断面積) }
\end{array}
$$

による算定值も示している，図からわかるように，式 (8)による推定值は, 圧縮の軸力に対する $d / D=0.44$ のジョイントの耐力変化率 $P_{c r} /\left.P_{c r}\right|_{N=0}$ にほぼ等しい.

\section{4 主管のスパン長さによる影響}

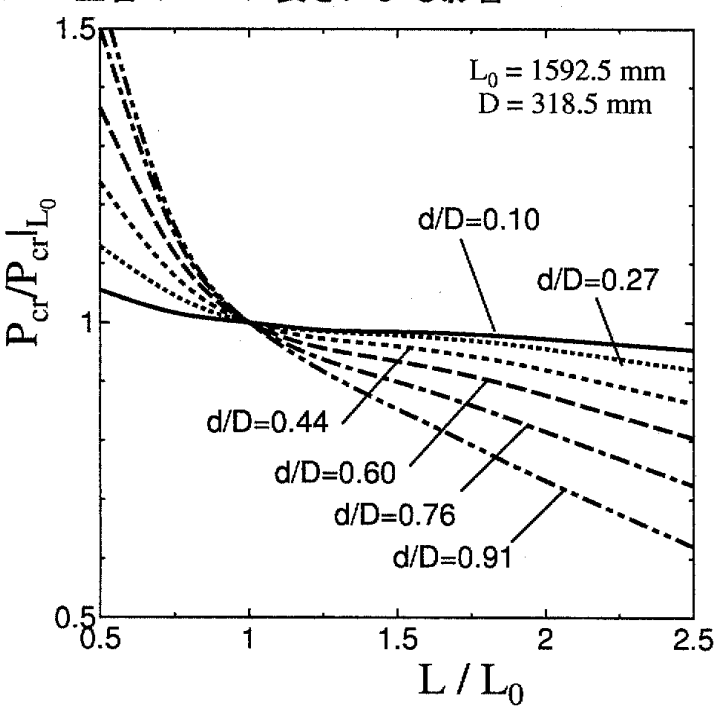

Fig. 13 Effect of span-length of chord on strength of Tjoint

図 13 は，長さ $L_{0}=1592.5 \mathrm{~mm}$ をスパンの基準長 さとして，種々の $d / D$ T ジョイントに対して求め た，スパンの長さ $L$ が変化するときの耐力 $P_{c r}$ の変化 $P_{c r} /\left.P_{c r}\right|_{L_{0}}$ を示すものである. 現在の耐力推定式には スパン長さ $L$ の影響はとくに考慮されていない，しか し，図 13 より分かるように，スパンが長くなるにつ れてジョイントの耐力は低下する.また， $d / D$ が小さ

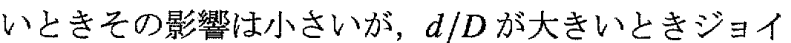
ントの而力に対するスパン長さ $L$ の影響は無視でき ないほど大きい，例えば， $d / D=0.91$ のジョイントに 対して， $L / L_{0}=2$ のときその耐力は約 $73 \%$ まで低下 する.

ジョイントの耐力に対するスパン長さの影響は，支 管の荷重 $P$ による主管の曲げ応力から検討できる，ま ず， $d / D$ が小さいときと大きいときの主管平面凹みに 対する支配領域が図 3 に示したようにそれでれ Side 部と Top 部であること，および主管の曲げ応力が Top 部で最大となることから， $d / D$ が小さいときスパンに
よる影響が小さいことは定性的に理解されるだるう。 次に, スパン長さの影響を, 荷重 $P$ による主管の曲げ 応力より定量的に検討してみる.

ここで，主管の Top 部での軸方向応力 $\sigma_{x}$ がある限 界忘力 $\sigma_{c r}$ に達するとき，ジョイントが耐力に達する と仮定する. そして軸方向応力 $\sigma_{x}$ を, 支管の押し込 妓によるローカルの応力 $\sigma_{l o c}$ と荷重 $P$ による主管 Top 部での曲げ応力 $\sigma_{g l o}$ との和であると考える。

$$
\sigma_{c r}=\sigma_{l o c}+\sigma_{g l o}
$$

応力 $\sigma_{l o c}$ はスパンの長さに無関係で, 耐力 $P_{c r}$ に比 例するから，それを式

$$
\sigma_{l o c}=\frac{k_{1}}{D T} P_{c r}
$$

で評価できる，一方，応力 $\sigma_{g l o}$ は荷重 $P$ による曲げ 応力であるため, スパン長さ $L に$ 比例し，それを式

$$
\sigma_{g l o}=\frac{k_{2}}{D^{2} T} P_{c r} L
$$

で評価できる. 式 (10) と (11)の中の $k_{1}$ と $k_{2}$ は未知 の係数である.

式 (9)〜(11) を用いれば，2つの異なるスパンに対 応する耐力の值から任意のスパンに対応する耐力を推 定することが可能である．例えば，スパン長さがそれ ぞれ $L_{a}$ と $L_{b}$ のジョイントに対応する耐力をそれぞれ $\left.P_{c r}\right|_{a}$ と $\left.P_{c r}\right|_{b}$ として, 任意のスパン長さ $L$ のジョイン 卜に対忘する耐力 $P_{c r}$ を以下のように推定することが できる. すなわち，式 (9)〜(11)より，スパン長さが それぞれ $L_{a} ， L_{b}$ と $L$ のジョイントに対して次式が成 り立つ.

$$
\left\{\begin{array}{l}
\sigma_{c r}=\left.\frac{k_{1}}{D T} P_{c r}\right|_{a}+\left.\frac{k_{2}}{D^{2} T} P_{c r}\right|_{a} L_{a} \\
\sigma_{c r}=\left.\frac{k_{1}}{D T} P_{c r}\right|_{b}+\left.\frac{k_{2}}{D^{2} T} P_{c r}\right|_{b} L_{b} \\
\sigma_{c r}=\frac{k_{1}}{D T} P_{c r}+\frac{k_{2}}{D^{2} T} P_{c r} L
\end{array}\right.
$$

式 (12) より, $\left.P_{c r}\right|_{a}$ と $\left.P_{c r}\right|_{b}$ に基づく, 長さ $L$ のジョ イントの耐力 $P_{c r}$ を推定する式

$$
P_{c r}=\frac{\left.\left.P_{c r}\right|_{a} P_{c r}\right|_{b}\left(L_{b}-L_{a}\right)}{\left.P_{c r}\right|_{a}\left(L-L_{a}\right)+\left.P_{c r}\right|_{b}\left(L_{b}-L\right)}
$$

が得られる。

図 14 に, $L_{a}=5 \mathrm{D}, L_{b}=10 \mathrm{D}$ として, 長さ $L=$ $3.75 D \sim 12.5 D$ のジョイトの耐力 $P_{c r}$ に対して式 (13) により推定した值と FEM の数值解析の結果との比較 を示す．図より長いスパン，例えば $L / D>4$ であれば 両者がほぼ一致していることが分かる。 


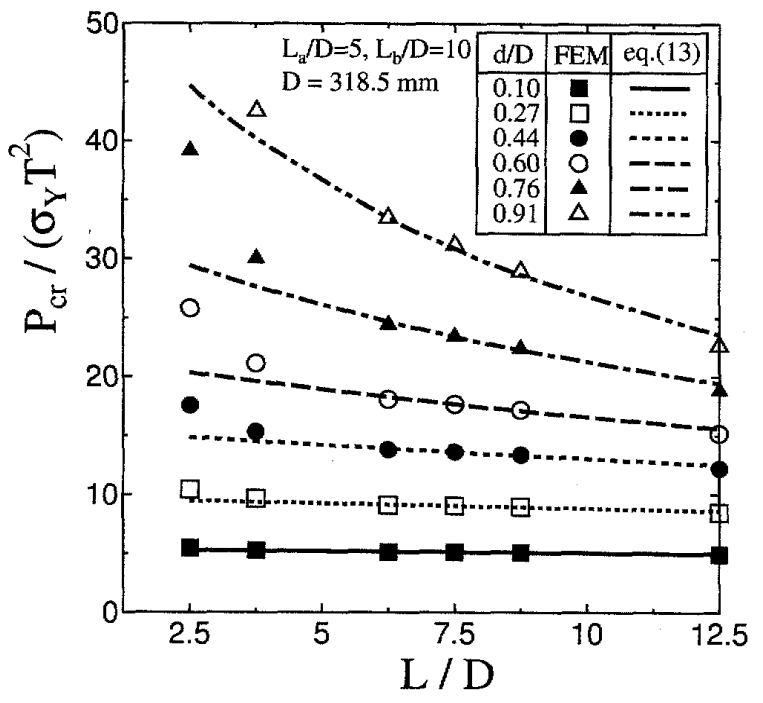

Fig. 14 Prediction results by using eq.(13)

また，スパンによる耐力への影響を，軸力による影 響として検討することも可能である。すなわち，式 (11) の曲げ応力 $\sigma_{g l o}$ による耐力の影響を, 主管の軸力 による影響と類似的なものとみなし，式 (8)に用いた 軸力比 $n$ を

$$
n=-\frac{k_{0}\left(\sigma_{g l o}-\sigma_{g l o} \mid 0\right)}{\sigma_{Y}}
$$

で評価できるものとする、ここに， $\left.\sigma_{g l o}\right|_{0}$ は，基準と するスパンの長さ $L_{0}$ における曲げ応力である.

式 (11) を式(14)に代入すれば，式

$$
n=-\frac{k_{0} k_{2}}{D^{2} T} \frac{\left(P_{c r} L-\left.P_{c r}\right|_{0} L_{0}\right)}{\sigma_{Y}}
$$

が得られる.ここに， $\left.P_{c r}\right|_{0}$ は基準スパン長さ $L_{0}$ に対 忘するジョイントの耐力である，また，係数 $k_{0} k_{2}$ につ いては，種々のスパンの長さに対する検討の結果によ $\eta$ ，近似的に $k_{0} k_{2} \cong 1 / 1.5$ とする.

よって，式 $(8)$ によれば， $P_{c r}$ に関する方程式

$$
\begin{aligned}
\frac{P_{c r}}{\left.P_{c r}\right|_{0}}=1- & 0.35\left(\frac{\left(P_{c r} L-\left.P_{c r}\right|_{0} L_{0}\right)}{1.5 D^{2} T \sigma_{Y}}\right) \\
& -0.35\left(\frac{\left(P_{c r} L-\left.P_{c r}\right|_{0} L_{0}\right)}{1.5 D^{2} T \sigma_{Y}}\right)^{2}
\end{aligned}
$$

が得られる.この2 次方程式を解けば，ある基準長さ $L_{0}$ に対応する耐力 $\left.P_{c r}\right|_{0}$ からスパン長さ $L$ のジョイン トの耐力 $P_{c r}$ を推定することができる.

図 15 に, $L_{0}=5 D$ として, 長さ $L=3.75 D \sim 12.5 D$ のジョイントの耐力 $P_{c r}$ に対して方程式 (16) から得た 耐力の推定值と FEM の数值解析結果との比較を示す. 図より長いスパン, 例えば $L / D>4$ であれば両者はほ ぼ一致することがわかる。

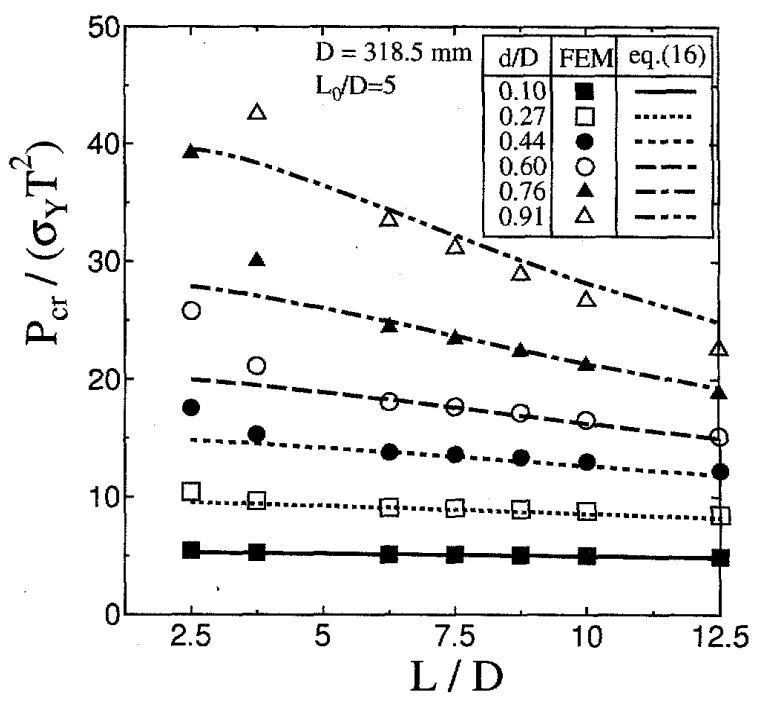

Fig. 15 Prediction results by using eq.(16)

なお，以上のようにスパン長さが耐力に影響するこ とは明らかであるが，実際の構造物の設計においてス パンの基準長さをどのように定義して設計式に適用す るかという課題は残る、このことについては，今後の 検討項目と考える.

\section{4. 結言}

鋼管ジョイント部の耐力は座屈や塑性降伏だけでは なく，溶接部の脆性破壊やパンチングシアなどにも起 因するが, 本研究では, 座屈と塑性降伏に起因する耐力 のみに注目し，支管と主管の直径比 $d / D=0.1 \sim 0.91$, スパンの長さ $L / D=2.5 \sim 12.5$ の範囲に対して, $\mathrm{T}$ 型 と $\mathrm{Y}$ 型の鋼管ジョイント部の耐力について, 沉用有限 要素法解析ソフトによる解析に基づき検討を行った。 その結果，以下の点が明らかになった。

(1) 支管と主管の直径比 $d / D$ が一定のとき, 耐力 $P_{c r}$ は， $P_{c r} \propto T^{\lambda}$ のように主管の肉厚 $T$ のべき乗 に比例するが，その指数入は， $d / B$ によって異な り $d / D$ が大きいほど小さい. $d / D=0.1 \sim 0.91$ の範囲では $\lambda \cong 1.93 \sim 1.55$ である.

(2) スパンが長くなるにつれてジョイントの耐力は 低下する．また， $d / D$ が小さいときその影響は小 さいが, $d / D$ が大きいときジョイントの耐力に対 するスパン長さ $L$ の影響は大きい，また，ジョイ ント耐力に対するスパン長さの影響は, 荷重 $P$ に よる主管の曲げ心力により検討することができる.

(3) 主管の軸圧縮力によってジョイントの耐力は低 下するが，その影響は T-ジョイントと Y-ジョイ ントにおいてほぼ同じ程度である。このような軸 
カによる影響は，主管の凹みが主に荷重 $P$ によっ て発生した軸方向応力 $\sigma_{x}$ により支配されること, およびこの軸方向応力 $\sigma_{x}$ が圧縮応力であること から理解される。

(4) $\mathrm{Y}-$ ジョイントの耐力 $\left.P_{c r}\right|_{Y}$ と, 同じ $d / D$ をもつ $\mathrm{T}$-ジョイントの耐力 $P_{c r}$ との間に, 常に $\left.P_{c r}\right|_{Y}<$ $P_{c r} / \sin \theta$ の関係があるが, 近似的に $\left.P_{c r}\right|_{Y} \cong$ $P_{c r} / \sin \theta$ が成り立つ. とくに, $\theta=45^{\circ}$, または $d / D$ が小さいとき，その誤差は小さい.

\section{文献}

(1) Architectural Institute of Japan, Recommendations for the design and fabrication of tubular truss structures in steel(2002), chaper 4.

(2) N. Akiyama, M. Yajima, H. Akiyama and F. Ohtake, Experimental study on strength of joints in steel tubular structures, (in Japaneses), Journal of Society of Steel Construction, 10(102), (1974), 37-68.

(3) H. Kanatani, Experimental study of welded tubular connection (Part 1), (in Japaneses), Transactions of Architectural Institute of Japan, 108, (1965), 31-39.

(4) Y. Makino, Y. Kurobane and Y. Mitsui, Ultimate strength of tubular joints for local failures due to compression braces, Transactions of Architectural Institute of Japan, 251, (1977), 45-55.

(5) K. Washio, T. Togo and Y. Mitsui, Experimental research on local failure of chord in tubular truss joints, Transactions of Architectural Institute of Japan, 140, (1967), 55-62.

(6) E. M. Dexter and M.M. Lee, Static strength of axially loaded tubular K-joints. I: Behavior, Journal of Structural Engineering, 125, (1999), 194-201. 